\title{
区画火災における開口噴流の流量測定 \\ MEASUREMENT FOR MASS FLOW RATE OF DOOR JET IN COMPARTMENT FIRES
}

\author{
山口純一*, 山田 茂**, 田中哮義***, 若 松孝旺**** \\ Jun-ichi YAMAGUCHI, Shigeru YAMADA, Takeyoshi TANAKA \\ and Takao WAKAMATSU
}

\begin{abstract}
Reduced scale experiments were conducted to measure the mass flow rate of door jet from a model fire compartment as the first step of the study on door jet plume and convective heat transfer in compartment fires.

As a results, the following findings have been obtained. (1) The mass flow rates of door jet can be obtained based on measurements of $\mathrm{O}_{2}$ concentration and $\mathrm{CO}_{2}$ concentration. (2) The mass flow rates of door jet calculated based on the gas analysis and the temperature measurement agreed well when 0.52 is used as the flow coefficient in the latter. (3) Heat release rates of fire source calculated based on gas concentration agreed in average with the heat release rate obtained from mass burning rate of fuel in the free space, but some of them differed significantly from the latter. The difference is thought to be caused by the change of fuel vaporization rate depending on ventilation factor of the compartment.
\end{abstract}

\section{Keywords : Flow Rate of Door Jet, Gas Analysis, Reduced Scale Test, Measurement Method 開口噴流の流量、ガス分析、模型実験、測定手法}

\section{1. 研究の背景と目的}

火災室等の室の開口部から噴出する高温ガスは、火災ブルームと 同様噴出した先の空間の空気を巻き込みながら上昇する。この開口 噴流プルームが建物内の空間で生ずると、空気の巻き込みが煙の举 動に及ぼす影響は著しいと考えられる。

開口噴流プルームに関連寸る既往の研究としては、横井の研究" がある。横井は空からの噴出火炎による上階延焼に関する研究にお いて、開口噴流プルームの温度分布を調べ、その予測手法を確立し た。しかし、開口噴流プルーム人の巻き込み空気量については実験 結果や予測結果を示していない。

開口噴流プルームの流量の実用的な扱いとしては、例えば開口噴 流プルームを便宜的に火災プルームと同じように垂直に上昇する熱 プルームと置き換えたモデル2゙があるが、実験的裏付けはない。

本来、開口噴流の巻き込み空気量を、このモデルのように単純に 垂直プルームと類似させた手法で、精度良く見糟もることは困難で あると思われる。その理由としては、(1)開口噴流は最初水平に吹き 出すが、後に浮力により上方に変わること、(2)噴出断面の形状とし て横長、縦長等種々の場合が考えられること、(3)開口の上部には壁 があることが多いが、その壁が存在することにより、自由空間のプ ルームに比較して巻き込みが制約されること等が举げられる。
そこで、この開口噴流プルームの巻き込み空気量を実験的に調へ ることとしたが、それにはその第一段階としてまず開口噴流の流量 の把握が必要とされる。

一方、筆者等は別に区画火災における対流䏶伝達の評価手法の確 立を目的とする研究を行っている ${ }^{3)}$ 。この研究においては、火災の 初期では火源の発熱に起因寸る流れが支配的と考えられるのに対し、 盛期火災時では開口を介しての自然換気による流れも影響すると考 えている。そして、盛期火災時の熱伝達性状を実験的に調べる際に、 [室内周壁への熱伝達速度 $]=[$ 発熱速度 $]-[$ 換気による失熱速度 $]$ であることから、熱伝達の性状を調べるためには、まず換気による 失熱速度を知ることが必要である。

寸なわち盛期火災の熱伝達性状を調べる実験においても、やはり 開口噴流の流量を把暒することが必要であり、その際上述の実験と 同じ装置及び実験手法が利用できると考えられたので、換気による 開口流量の測定手法について共通の検討をすることとした。

\section{2. 研究の方法}

模型実䀦における開口噴流の流量を測定することが目的であるが、 火災区画模型の小さな開口部を通る噴流の流速分布を測定すること は技術的に極めて困難なので、以下の 2 通りの方法を考えた。
* 東京理科大学大学院理工学研究科建築学尃攻 工修

** フジ夕技術研究所 博士 (工学)

*** 京都大学防災研究所 教授. 工博

**** 東京理科大学理工学部建築学科 教授·工博
Graduate Student, Dept. of Architecture, Faculty of Sci. and Tech., Science Univ. of Tokyo, M. Eng.

Technical Research Institute, Fujita Corporation, Dr. Eng. Prof., Disaster Prevention Research Institute, Kyoto Univ., Dr. Eng. Prof., Dept. of Architecture, Faculty of Sci. and Tech., Science Univ. of Tokyo, Dr. Eng. 


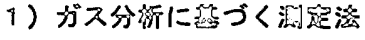

図 1 にガス分析に基づく流量測定システムの縄念を示す。

關口喷流はプルームとなって上昇する過程で周囲空気を巻き込む ことにより神致される。プルームに含まれる $\mathrm{O}_{2}$ や $\mathrm{CO}_{2}$ の筑度はそ の希牧の程度により変化するが、然焼が区画内で完結し、外での焱

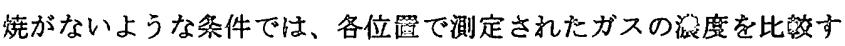
ることにより、それぞれの位㯰における流量が筀出できるというの が基本的考え方である4)。

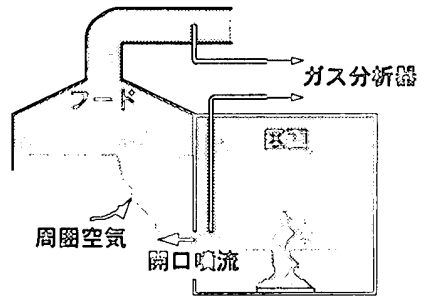

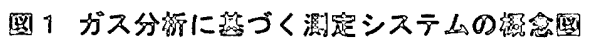

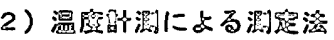

区画内温度を一様と仮定すると、開口部に沾ける圧力差及び流薏 分布は図2のようになり、この時開口からの流出速度は一般に下式 で表される。

$$
m_{D}=\frac{2}{3} \alpha B\left(2 g \rho s\left(\rho_{a}-\rho s\right)\right)^{1 / 2}\left(H-Z_{n}\right)^{s / 2} \quad \ldots \text { (1) }
$$

これは、必要とされる測定星が温度のみであり、筬侕に求められ

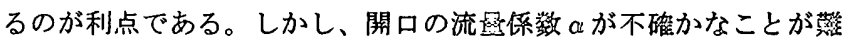
点である。

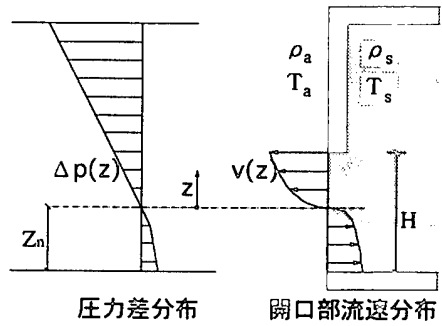

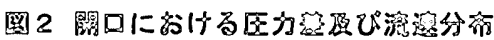

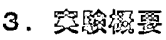

図 3 に火災区画模型とガス捕篹装圆及び測定位四を示す。

3. 1 火災国國溜烈

火災区画模型は、厚さ $12 \mathrm{~mm}$ のパーライト板に厚さ $3 \mathrm{~mm}$ のステ ンレス板を内貼りした内法一辺 $1,500 \mathrm{~mm}$ の立方体である。ただし、 ステンレス板の内貼りは鵁伝達性状を調べる祭に必要となる内表面 温度を測定するためのもので、本諭文には直接関低しない。

区画の開口条件は、形状の異なる開口パネルを职付けることによ

り、変化させることができるようにした。

底面中央部にはアルコールパンを設器した。径の暴なるパンを用 いることにより発熟速度を変化させることができる。然料としては メタノールを使用した。

關口の外部上方には關口から流出するガスを捕集するため、大フ ード $\left(1,000 \times 1,000 \times 650^{\mathrm{h}} \mathrm{mm}\right)$ を設置した。大フードにはダクト を接続し、その端部には捕算ガスを吸引するための蚌気ファンを設 四した。ダクト内には流鼠測定のためのオリフィスを取り付けてい
る。

なお、この下に、高さを可変としたパーライト板製の小フード $\left(800 \times 800 \times 400^{\mathrm{h}} \mathrm{mm}\right)$ を設圈しているが、これは開口㜔流プルーム の流承の㨽定において巻き込み高さを明確にするため Zukoski 等" の手法にならったもので、開口咥流の流是を測定する目的だけでは 特に必要はない。しかし、閶口噴流プルームの測定では合わせて開

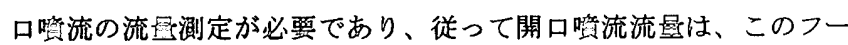
ドの存在及び高さの如何に閞わらず測定できる必要がある。

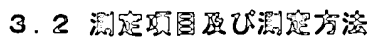

本赛飡における測定項目は次の通りである。なお、これらの測定 位圈は图 3 中に示している。

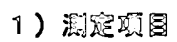

- 区面内空気温度：垂直方向 11 点 $\times$ 平面上の 2 ヶ所

。關口部温度 : 關口上端から下端まで $30 \mathrm{~mm}$ 間隔、 開口端から $30 \mathrm{~mm}^{\text {i土1) }}$

。小フード内温度 : 垂直方向 6 点 $(80 \mathrm{~mm}$ 間桎 $)$

。周辺空気温度

。ガス没度（区画内、小フード内、排気ダクト内）

。排気ダクト内オリフィス板前後差压、空気温度

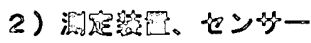

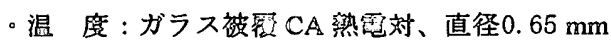

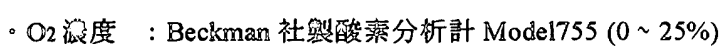

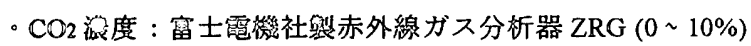

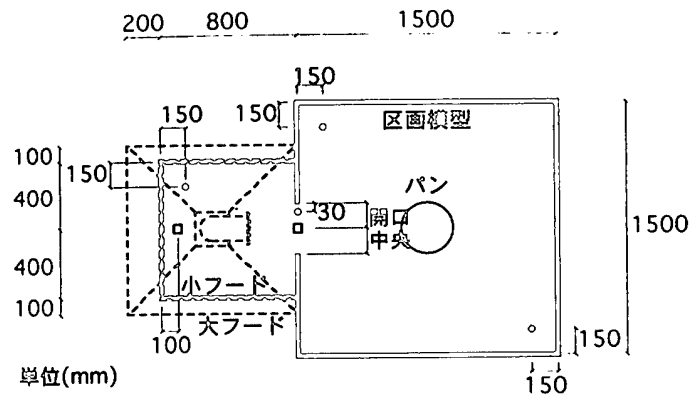

(1) 郚面圆

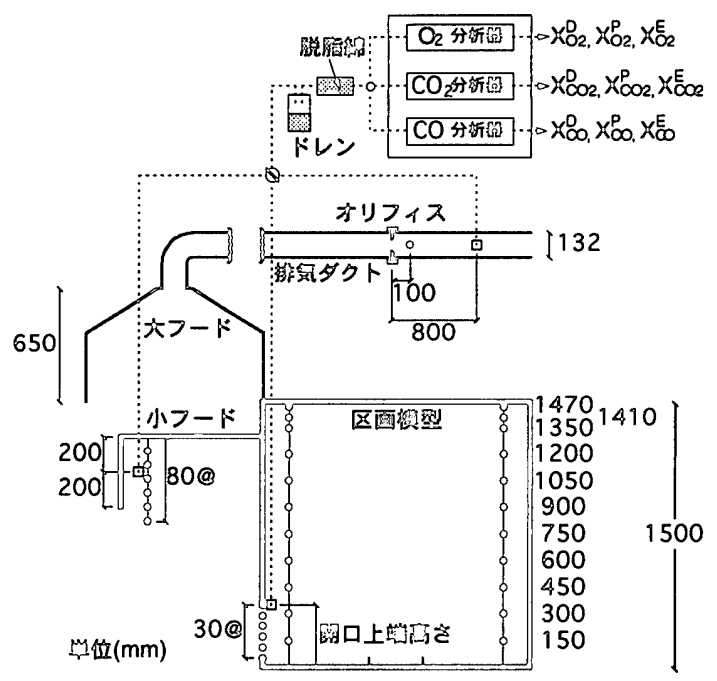

(2) 路䤄图

ロガス採取位圆

$\bigcirc$ 温度測定位置

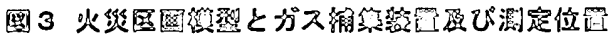


- $\mathrm{CO}$ 濃度 : 富士電機社製赤外線ガス分析器 ZRG (0 2\%)

- 差 圧 : Validyne 社製差圧計

測定間隔は 2 秒とし、データはデータロガー、パソコンにより自 動計測・収録した。

\section{3 実験条件}

開口寸法、パン径、小フード高さを変化させ、全ての組み合わせ について測定を行った。以下にそれぞれの条件を示す。

\section{1 ) 開口形状}

開口は表 1 に示寸 8 種類である。なお、開口の下端は全ての条件 において床面から50mmである。

\section{表 1 開口形状}

\begin{tabular}{r|r|r|r|r|r|r|r|r}
\hline 幅 B (mm) & 150 & 150 & 300 & 300 & 300 & 450 & 450 & 450 \\
\hline 高さH (mm) & 300 & 450 & 150 & 300 & 450 & 150 & 300 & 450 \\
\hline
\end{tabular}

\section{2) パン径と発熱速度}

パン径を表 2 に示す。哚さは $20 \mathrm{~mm}$ である。パンは休に接して設 置した。なお表中の発熱速度は参考のため示したが、自由空間での 燃焼における重量减少速度から算出したものであるき。

\section{表 2 パン径と発熱速度}

\begin{tabular}{l|r|r|r}
\hline パン 径 $(\mathrm{mm})$ & 150 & 200 & 250 \\
\hline 発熱速度 $(\mathrm{kW})$ & 4.0 & 6.6 & 10.6 \\
\hline
\end{tabular}

\section{3) 小フード高さ}

小フードのたれ壁下端高さと区画開口上端の距離を 500、400、 300、200、100、50、0 mm の 7 段階とした。高さを变えたのは開口 噴流プルームの流量と空気巻き込み高さについて調べるためである。

\section{4 実験の手䐓}

着火後20分程度で各測定值がほぼ一定となり、定常と考えられる 状態になるのが確認された。その後、火源を燃焼させたまま、小フ ード高さを変化させて連続的に実験を行った。高さを変化させてか らは $2 \sim 3$ 分程度でほぼ定常状態になった。データの収録はこの定 常状態とみなせる時期に行った。然料は小フードの高さを変えた直 後に供給した。

ガス分析器は同一のものを使用し、採取位置（区画内、開口部上 部、小フード内、排気ダクト内）を切り替えながら各位置からの採 取ガスの $\mathrm{O}_{2} 、 \mathrm{CO}_{2}$ 及び $\mathrm{CO}$ 浱度を交互に測定した。1 台の分析器を 使用したのは、分析計の指示差による誤差を避けるためで、この際 に定常状態における測定のために濃度の時間的変化がないことを利 用している。なお、周辺空気のガス漂度は火源への着火以前の值を もって換えた。

小フード高さを 7 段階変化させ、計測を行った後、火源を鎮火さ せた。そして、開ロパネル及びアルコールパンを变え、次の実験を 行った。

\section{4.ガス分析による流量の算定法}

4. 1 開口噴流の流量算定

本実験における各流量とガスの質量分率の関係を図 4 に示す。

\section{1）質黄及びガスの保存と算量流速}

図 4 の系において、小フードに流入する量は、開口からの流出量 $\mathrm{m}_{\mathrm{D}}$ と開口噴流プルームに巻き込まれる空気量 $\mathrm{ma}$ の合計であり、
これはまた小フードから流出する量 $\mathrm{m} P$ に等しいので、小フードの 質量の保存から

$m_{D}+m_{a}=m_{P}$

また大フードでは、小フードからの流出量 $\mathrm{m} P$ と、新たに巻き込 まれる空気量自合の計が排煙される量 $\mathrm{m}_{\mathrm{E}}$ に等しいから

$m_{P}+m_{a^{\prime}}=m_{E}$

次いで小フードのガスの質量保存から

$Y_{L}^{D} m_{D}+Y_{L}^{a} m_{a}=Y_{L}^{P} m_{P}$

また、大フードのガスの質量保存から

$Y_{L}^{P} m_{P}+Y_{L}^{a} m_{a}^{\prime}=Y_{L}^{E} m_{E}$

ただし、Lはガスの種類、すなわち $\mathrm{O}_{2}$ または $\mathrm{CO}_{2}$ を表す。また、 $\mathrm{Y}_{\mathrm{L}}$ はガスの質量分率、添字 D、P、E及び $\mathrm{a}$ はそれぞれ開口噴流、 小フード、大フード（排気ダクト）及び周辺空気を表す。

式(2)〜式(5)より、 $\mathrm{m}_{\mathrm{D}}$ 及び $\mathrm{m}_{\mathrm{P}}$ はそれぞれ下式で表される。

$$
m_{D}=\frac{Y_{L}^{a}-Y_{L}^{E}}{Y_{L}^{a}-Y_{L}^{D}} m_{E}
$$

及び

$$
m_{P}=\frac{Y_{L}^{a}-Y_{L}^{E}}{Y_{L}^{a}-Y_{L}^{P}} m_{E}
$$

従って各位置におけるガスの質量分率、及びダクト内におけるガ スの質量流速を測定すれば、開口噴流の質量流速が得られることに なる。なお、式(6)は小フードがない場合でも成立する。

\section{2）探取ガスの質量分率}

式(6)または式(7)から、 $\mathrm{m}_{\mathrm{D}}$ または $\mathrm{m}_{\mathrm{P}}$ を求めるためには、ガス の質量分率が知られなければならない。しかし、ガス分析器で測定 されるのは体積分率である。また、各位膡での採取ガス中には水分 $\left(\mathrm{H}_{2} \mathrm{O}\right)$ が含まれるが、ガス分析器に入る前にこの水分を除去するた め、分析されるガス中に占める $\mathrm{O}_{2} 、 \mathrm{CO}_{2}$ の体積分率の測定值は、 採取ガス中の実際の $\mathrm{O}_{2} 、 \mathrm{CO}_{2}$ の体積分率とは異なることになる。

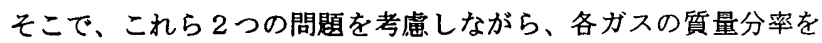
求める手順を以下に示す。

\section{1）採取ガスの体積分率と貿量分率}

採取ガス中のガス $\mathrm{L}$ の体糟分率 $\mathrm{X}_{2}$ と質量分率 $\mathrm{Y}_{2}$ の関係は

$$
Y_{2}=\frac{M_{L} X_{L}}{M_{02} X_{O 2}+M_{C O 2} X_{C O 2}+M_{N 2} X_{N 2}+M_{H 2 O} X_{H 2 O}} \cdots \text { (8) }
$$

となる。ここで、 $M_{L}$ はガス Lの分子量である。また微量ガスは無 視し、CO は検出されなかったので、採取ガス中には $\mathrm{O}_{2} 、 \mathrm{CO}_{2} 、 \mathrm{~N}_{2}$ 及び $\mathrm{H}_{2} \mathrm{O}$ しか存在しないと仮定した。

さらに、上記の任意の採取位置における気体中の各ガスの体積分 率の間には

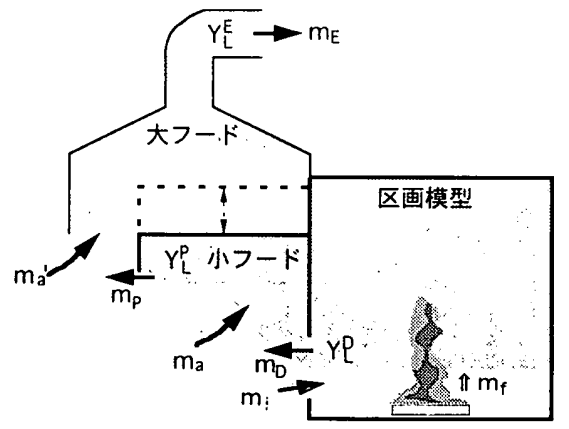

図4 各流量とガスの質量分率 
$X_{\mathrm{O} 2}+X_{\mathrm{CO}}+X_{N 3}+X_{\mathrm{H}_{2} \mathrm{O}}=1$

の関䇣がある。

一方、分析器に入るガスからは隶分 $\left(H_{2} 2 \mathrm{O}\right)$ が除去されているため、

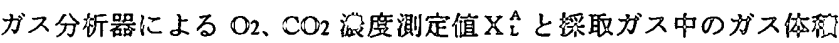
分率 $\mathrm{X}_{\mathrm{L}}$ との間にはそれぞれ

$$
X_{O 2}^{A}=\frac{X_{O 2}}{X_{O 2}+X_{C O 2}+X_{N 3}}
$$

及び

$$
X_{\mathrm{CO} 2}^{A}=\frac{X_{\mathrm{CO}_{2}}}{X_{\mathrm{OA}}+X_{\mathrm{CO} 2}+X_{\mathrm{N2}}}
$$

の關係がある。なお、N 2 淑度は測定できないが、ガス分析器に入 る $\mathrm{N}_{2}$ の旅度を $\mathrm{X}_{\mathrm{N} 2}^{\mathrm{A}}$ とすると

$X_{O 2}^{A}+X_{C O 3}^{A}+X_{N 2}^{A}=1$

の関係がある。

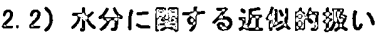

实䟻では水分は測定しないので、以下のような近似的彶いをする。 然料として用いたメタノールの签锛化学式は

$$
\mathrm{CH} 3 \mathrm{OH}+\frac{3}{2} \mathrm{O}_{2} \rightarrow \mathrm{CO}_{2}+2 \mathrm{H}_{2} \mathrm{O}
$$

であり、O2 3 モルの消党に封し $\mathrm{H}_{2} \mathrm{O}$ が 4 モル登坐することになる

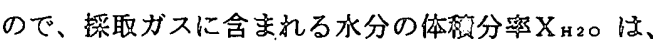

$$
X_{H 2 O}=\frac{4}{3}\left(X_{O 2}^{a}-X_{O 2}\right)
$$

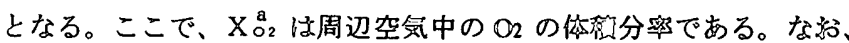

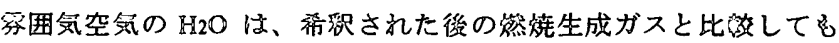
十分に小さいと考え無視した。

きた、 $\mathrm{CO}_{2} 1$ モル発生に对し、 $\mathrm{H}_{2} \mathrm{O}$ が 2 モル發生するとも㘷えら

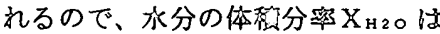

$$
X_{\mathrm{H} 2 \mathrm{O}}=2\left(X_{\mathrm{CO} 2}-X_{\mathrm{CO} a}^{a}\right)
$$

とも福ける。

次に、式(14)を式(9)に代入すると

$$
X_{N 2}=1+\frac{1}{3} X_{O 3}-\frac{4}{3} X_{02}^{a}-X_{C O 2}
$$

また、式(15)を式(9)に代入すると

$$
X_{N 2}=1-X_{O 2}-3 X_{C O 2}+2 X_{C O 3}^{a}
$$

となる。従って、式(14) 及び式(16)を式(8)に代入することにより、 测定にのらないX $\mathrm{X}_{\mathrm{H} 20}$ と $\mathrm{X}_{\mathrm{N} 2}$ を消去すると、䌽职ガス中の O2 の颃 分分率 $Y_{02}$ は

$$
Y_{O_{2}}=\frac{24 X_{O_{2}}}{21+13 X_{O_{2}}+12 X_{C O 2}-10 X_{03}^{a}}
$$

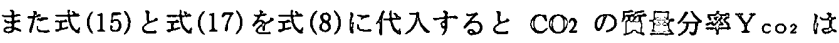

$$
Y_{\mathrm{CO} 2}=\frac{11 X_{\mathrm{CO} 2}}{7+X_{\mathrm{O} 2}-X_{\mathrm{CO} 2}+5 X_{\mathrm{COz}}^{a}}
$$

一方で式(16)を式(10)に代入すると䌽取ガス中の O2 の测定值 (仵椟分率) は

$$
X_{02}^{A}=\frac{X_{03}}{\frac{4}{3}\left(X_{02}-X_{02}^{a}\right)+1}
$$

また、式(17)を式(11)に代入すると、採取ガス中の $\mathrm{CO}_{2}$ の測定唒仗

$$
X_{\mathrm{CO} 2}^{A}=\frac{X_{\mathrm{CO} 3}}{2\left(X_{\mathrm{CO} 2}^{a}-X_{\mathrm{CO} 3}\right)+1}
$$

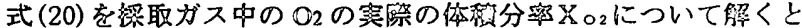

$$
X_{02}=\left(\frac{4 X_{O 3}^{2}-3}{4 X_{O 3}^{A}-3}\right) X_{O 3}^{A}
$$

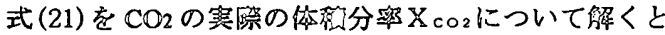

$$
X_{\cos }=\left(\frac{2 X_{c O s}^{a}+1}{2 X_{c o s}^{A}+1}\right) X_{C O s}^{A}
$$

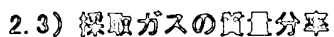

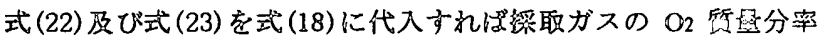
$\mathrm{Y} 02$ 新

$$
Y_{03}=\frac{24\left(4 X_{O 2}^{a}-3\right) X_{O 3}^{A}}{\left(21-10 X_{O 3}^{a}\right)\left(4 X_{O 2}^{A}-3\right)+\left(13 X_{O 3}^{A}+12 X_{C O 2}^{A}\right)\left(4 X_{03}^{a}-3\right)}
$$

また、式(22) 及び式(23)を式(19)に代入すれば、採取ガスの $\mathrm{CO}_{2}$

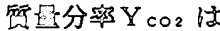

$$
Y_{C O Z}=\frac{11\left(2 X_{C O 3}^{a}+1\right) X_{C O 3}^{A}}{\left(7+5 X_{C O 3}^{a}\right)\left(2 X_{C O Z}^{A}+1\right)+\left(X_{O S}^{A}-X_{C O Z}^{A}\right)\left(2 X_{C O E}^{a}+1\right)}
$$

となる。式(24)及び式(25)において、測定僆 $\mathrm{X}_{\mathrm{L}}^{\mathrm{A}}$ として、それぞれ

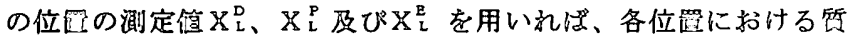
亟分的が求められる。

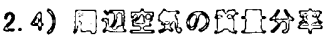

周辺空氛中の $\mathrm{H}_{2} \mathrm{O}$ 经登福するので、式(8)及び式(9)で $\mathrm{X}_{\mathrm{H}_{2} \mathrm{O}}=0$

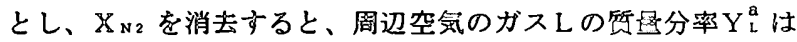

$$
Y_{L}^{a}=\frac{M_{L} X_{L}^{a}}{28+4 X_{o s}^{a}+16 X_{c o s}^{a}}
$$

従って、周辺空気の $\mathrm{O}_{2}$ 及び $\mathrm{CO}_{2}$ 咓贫分率 $\mathrm{Y}_{02}^{\mathrm{a}}$ 及び $\mathrm{Y}_{\mathrm{co} 2}^{\mathrm{a}}$ は

$$
Y_{O 3}^{a}=\frac{8 X_{03}^{a}}{7+X_{O 3}^{a}+4 X_{C O 3}^{a}}
$$

及び

$$
Y_{C O 3}^{a}=\frac{11 X_{C O 3}^{a}}{7+X_{O 3}^{a}+4 X_{C O 3}^{a}}
$$

以上から、式(24)、式(25)、式(27)及び式(28)を、式(6)及び式 (7)に代入ずれば $\mathrm{m}_{\mathrm{D}}$ 及び $\mathrm{m}_{\mathrm{P}}$ が得られることとなる。

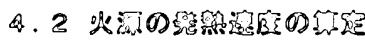

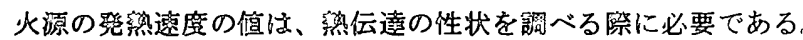

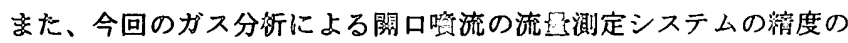
徐証に利用できる可能等もある。この発熟透度は図 4 の系での O2

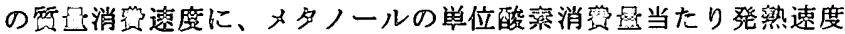
$13,220 \mathrm{~kJ} / \mathrm{kg}\left(\mathrm{O}_{2}\right)$ を桑ずれ得られる。

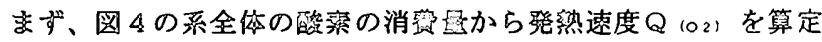
するには、

$Q(03)=13,220\left\{Y_{O 3}^{a}\left(m_{i}+m_{a}+m_{a}^{\prime}\right)-Y_{O z}^{E} m_{E}\right\}$

となる。一方、罂鮆保疗から

$$
m_{D}=m_{i}+m_{f}
$$

及び

$m_{E}=m_{D}+m_{a}+m_{a}$ 

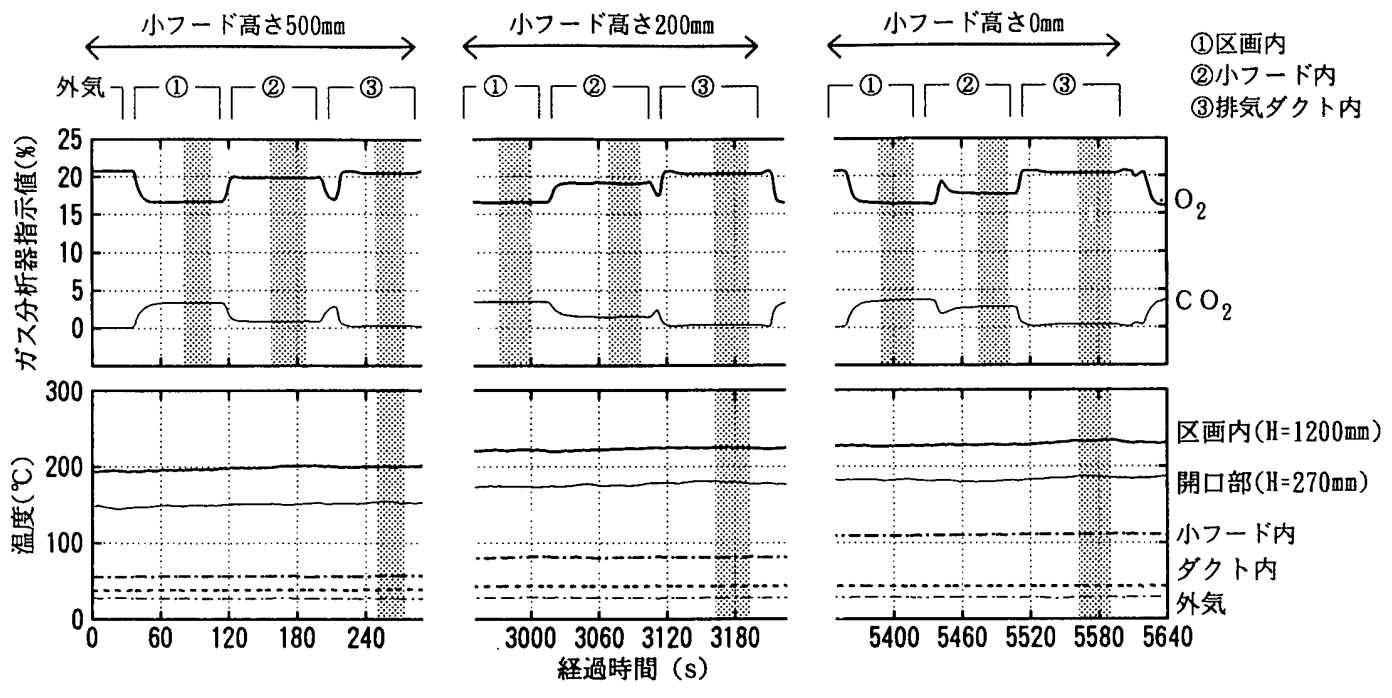

図 5 測定値の経時変化

$m_{B}=m_{i}+m_{f}+m_{a}+m_{a}^{\prime}$

であるが、開口からの流入量 $\mathrm{mi}$ 及び空気の巻き込み量 $\mathrm{ma}$ 及び ma'に比較し、メタノールの蒸発速度 $\mathrm{m} f$ は無視できる注2) から

$m_{E} \div m_{i}+m_{a}+m_{a}$

従って

$$
\begin{aligned}
Q_{(02)} & =13,220\left\{Y_{O 2}^{A}\left(m_{i}+m_{a}+m_{a}^{\prime}\right)-Y_{O 2}^{E} m_{E}\right\} \\
& =13,220\left(Y_{O 2}^{a}-Y_{O 2}^{E}\right) m_{E}
\end{aligned}
$$

つまり、雲囲気空気とダクト内の $\mathrm{O}_{2}$ の質量分率、及びダクト内 の流量速度から発熱速度が算出できることになる。

一方、燃料メタノールの燃焼反応の化学式 (13) から、 $\mathrm{CO}_{2} 2$ モル の発生に対して $\mathrm{O}_{2}$ が 3 モル消費されていることから、 $\mathrm{CO}_{2}$ 濃度の 変化を利用して、下式でも算出できる。

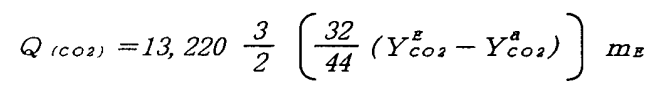

\section{5. 実験結果と考察}

\section{1 測定值の経時変化}

区画内、開口部、小フード内、ダクト内及び外気の空気温度、並 びに $\mathrm{O}_{2}$ 及び $\mathrm{CO}_{2}$ の体積分率 (分析器指示值) の計測中の経時変化 の様子を、パン径 $20 \mathrm{~mm}$ 、開口 $30 \times 30^{\mathrm{h}} \mathrm{mm}$ の場合について、図 5 に 例示する。なお、いずれの実験でも区画内での Co 発生は認められ なかったことから、メタノールは区画内で完全燃焼していたと考え られる。

着火後、約20分を経過してからデータの収録を開始しているので、 区画内及びダクト内の温度はほぼ定常と見なせる状態になっている。 ガス濃度は 1 台のガス分析器を用いて各ガス採取位置を切り替え て測定しているが、切り替光後20〜30秒程度で指示值はほぼ定常に 達している。開口噴流と開口噴流プルームの流量、及び発熱速度等 の算定のデータとしては、この約 1 分後から30秒間の平均值を用い ているが、図ではこの部分を網掛けで示している。

小フード高さを変えると小フード内の温度及びガス漊度が変化す るのは、巻き込み空気量が変化するためである。一方、小フードの 高さを変えても区画内の浼度に変化がないのは当然であるが、ダク
ト内の濃度もほとんど変化しない。

\section{2 開口噴流及び開口韻流プルームの質量流速}

パン径 $20 \mathrm{~mm}$ 、開口 $30 \times 30^{\mathrm{h}} \mathrm{mm}$ の場合の、開口噴流の質量流速 $\mathrm{m}_{\mathrm{D}}$ 及び開口噴流プルームの質量流速 $\mathrm{m}_{\mathrm{P}}$ と、小フード高さとの関 係の一例を図 6 に示す。

小フード高さが高くなるほど、開口噴流プルームの量は増加して おり、巻き込み空気量が増加しているのがわかる。一方、開口噴流 の量は小フード高さには依存しないのは当然である。

なお、それぞれの流量は $\mathrm{O}_{2}$ 濃度及び $\mathrm{CO}_{2}$ 濃度のいずれからも算 出できるが、両者は良く一致している。

表 3 には、全ての条件における開口噴流の質量流速を示寸。 $\mathrm{O} 2$ 濃度から算出した開口噴流の質量流速を $\mathrm{m} 。\left(\mathrm{O}_{2}\right) 、 \mathrm{CO}_{2}$ 濃度から算 出した值を $\mathrm{m}_{\mathrm{D}}\left(\mathrm{CO}_{2}\right)$ とし、このそれぞれの值とこれら 2 つの平均值 を示している。なお小フード高さは 7 段階に変化させて、その都度 測定を行っているが、図 6 に例示したように小フード高さは開口噴 流の質量流速には関倸しないことがわかっているので、表にはこの 7 回の測定值の平均を示した。

図 7 には $\mathrm{O}_{2}$ 及び $\mathrm{CO}_{2}$ 濃度から算出した開口噴流の質量流量上、

これらの平均値との関係を示した。

表 3 及び図 7 から、開口噴流の流量が小さい場合には $\mathrm{O}_{2}$ 濃度か ら算出した值と $\mathrm{CO}_{2}$ 穠度から算出した值は良く一致しているのが わかる。一方、流量が大きくなると $\mathrm{O}_{2}$ 潾度から算出した值が $\mathrm{CO}_{2}$

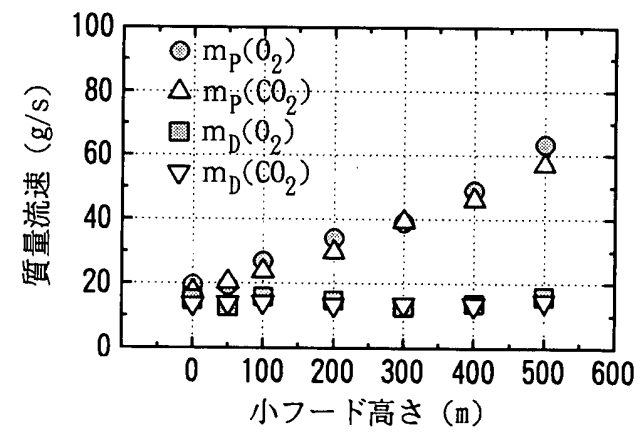

図 6 小フード高さと、開口噴流及び開口噴流プルームの質量流速 （パン径 $20 \mathrm{~mm} 、$ 開口 $30 \times 30^{\mathrm{h}} \mathrm{mm}$ ) 


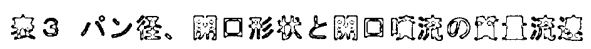

\begin{tabular}{|c|c|c|c|c|c|}
\hline \multirow{2}{*}{$\begin{array}{l}\text { パン径 } \\
\text { (匹) }\end{array}$} & \multicolumn{2}{|l|}{ 開 } & \multicolumn{3}{|c|}{ 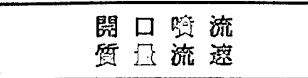 } \\
\hline & $\begin{array}{l}\text { 唒 } \\
\text { (ㅁ) }\end{array}$ & 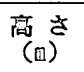 & $\begin{array}{c}\mathrm{m}_{\mathrm{o}}(02) \\
(\mathrm{g} / \mathrm{s})\end{array}$ & $\begin{array}{c}\mathrm{m}_{\mathrm{o}}(\mathrm{CO}) \\
(\mathrm{g} / \mathrm{s})\end{array}$ & $\begin{array}{l}\text { 平均 } \\
(\mathrm{g} / \mathrm{s})\end{array}$ \\
\hline 0.15 & $\begin{array}{l}0.15 \\
0.15 \\
0.30 \\
0.30 \\
0.30 \\
0.45 \\
0.45 \\
0.45\end{array}$ & $\begin{array}{l}0.30 \\
0.45 \\
0.15 \\
0.30 \\
0.45 \\
0.15 \\
0.30 \\
0.45\end{array}$ & $\begin{array}{r}4.6 \\
10.6 \\
4.9 \\
11.6 \\
23.0 \\
6.8 \\
17.1 \\
31.9\end{array}$ & $\begin{array}{r}4.3 \\
9.3 \\
4.5 \\
9.7 \\
16.1 \\
5.9 \\
13.0 \\
22.2\end{array}$ & $\begin{array}{r}4.5 \\
10.0 \\
4.7 \\
10.6 \\
19.6 \\
6.4 \\
15.0 \\
27.0\end{array}$ \\
\hline 0.20 & $\begin{array}{l}0.15 \\
0.15 \\
0.30 \\
0.30 \\
0.30 \\
0.45 \\
0.45 \\
0.45\end{array}$ & $\begin{array}{l}0.30 \\
0.45 \\
0.15 \\
0.30 \\
0.45 \\
0.15 \\
0.30 \\
0.45\end{array}$ & $\begin{array}{r}6.4 \\
13.2 \\
4.9 \\
14.3 \\
23.5 \\
6.1 \\
20.6 \\
33.1\end{array}$ & $\begin{array}{r}6.7 \\
12.3 \\
5.5 \\
13.8 \\
21.4 \\
6.8 \\
16.1 \\
26.1\end{array}$ & $\begin{array}{r}6.6 \\
12.8 \\
5.2 \\
14.1 \\
22.4 \\
6.4 \\
18.4 \\
29.6\end{array}$ \\
\hline 0.25 & $\begin{array}{l}0.15 \\
0.15 \\
0.30 \\
0.30 \\
0.30 \\
0.45 \\
0.45 \\
0.45\end{array}$ & $\begin{array}{l}0.30 \\
0.45 \\
0.15 \\
0.30 \\
0.45 \\
0.15 \\
0.30 \\
0.45\end{array}$ & $\begin{array}{r}5.7 \\
11.5 \\
4.3 \\
14.9 \\
28.7 \\
6.5 \\
20.7 \\
43.3\end{array}$ & $\begin{array}{r}6.4 \\
11.4 \\
5.3 \\
15.1 \\
26.6 \\
7.9 \\
21.0 \\
35.5\end{array}$ & $\begin{array}{r}6.1 \\
11.4 \\
4.8 \\
15.0 \\
27.7 \\
7.2 \\
20.8 \\
39.4\end{array}$ \\
\hline
\end{tabular}

湖度から算出した值よりもやや大きくなる傾向が見られるが、平均

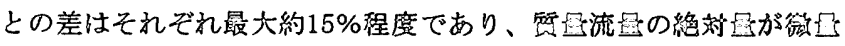

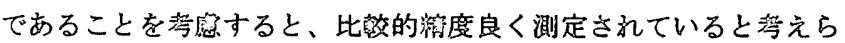
れる。

$\mathrm{m}_{\mathrm{D}}\left(\mathrm{O}_{2}\right)$ と $\mathrm{m}_{\mathrm{D}}\left(\mathrm{CO}_{2}\right)$ とで若干の差がある埸合を棓虑し、來研究で

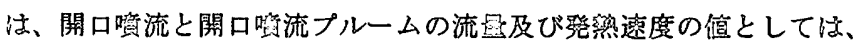
$\mathrm{O}_{2}$ 被及び $\mathrm{CO}_{2}$ 没度から等出した 2 つの值の平均值を用いること

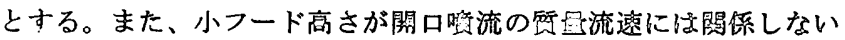

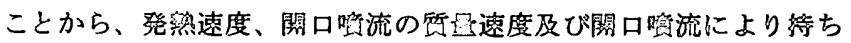

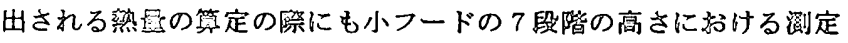
值の平均を使用する。

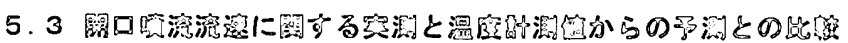

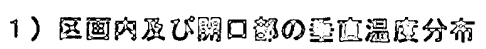

区画内及び開口部の垂直温度分布の一例（パン径 $20 \mathrm{~mm}$ 、關口 30

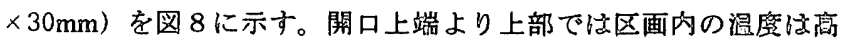
温でほぼ均一となっており、一方、床上150mm の位目では低沼を 示していることから、上部高温网及び下部低温層という二居を形成 していることが藋われる。さらに、關口部に屷ける温磨は、上部で は区画内の同じ高さの温度とほぼ等しく下部では低くなっているこ とから、上部から關口㩐流が流出し下部では外部空気が流入してい
ることがわかる。

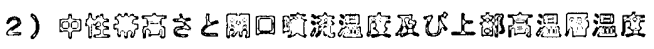

式(1)により、温店計測傎を用いて開口啐流の流速を推定する場 合に怡中性需高さを知ることが必票となるが、流入と流出の境界の 高さが中性蒂の高さであるから、以下に示すように、開口部の温度 計湘得から中经常の高さを灌定した。

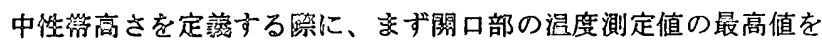

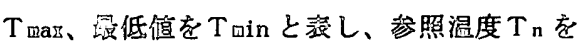

$$
T_{n}=N\left(T_{\max }-T_{\min }\right)+T_{\min }
$$

とした。そして測定佂を直線補間して、Tn を示す高さを算出し、 これを中笹蒂高さとした。

ここで、図 8 に例示した閶口部の真温度分布をみると、外部か ら空武肪流入していると洼えられる閣口下部ではその温度はほほ外 部温廢に等しく、ある位四から急勾配で上昇する。中性帯汢この温 店が急に上界している高さ付近にあると考えられる。一般に $N=$ 0.10〜0.15とされる゙が、急勾配の温度分布からみて、この筑囲の

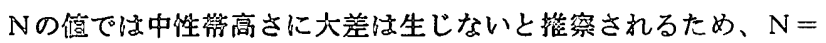
0.1とした。きた上部高漫居の温度としては、中性带から開口上 端きでの高さの区画内温噔の平约徝を用いた。

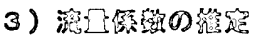

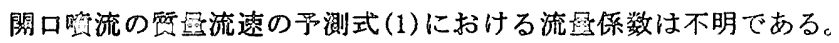

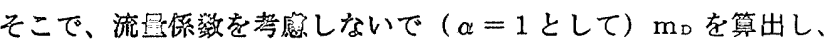
ガス分析による害測值と比したものを图 9 に示す。

ややテータに袮らばりにあるが、 的良く近似できると涄えられる。単純開口の湯合、既往の測定值は

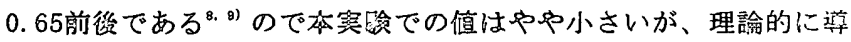

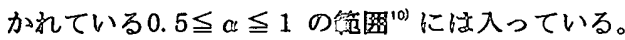

な放、式(35)のNの犆を大きくとると 例え

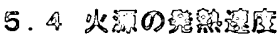

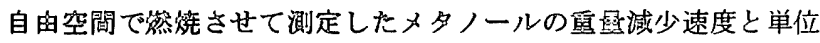

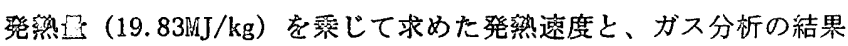

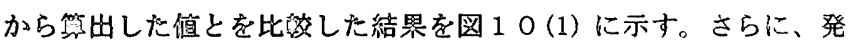

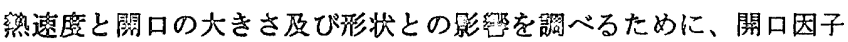

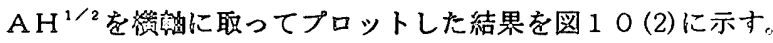

图 10 (1) を見ると、而者心就为一致しているが最大 $25 \%$ 程度 の差も見られる。この原图としては以下のようなことが考えられる。

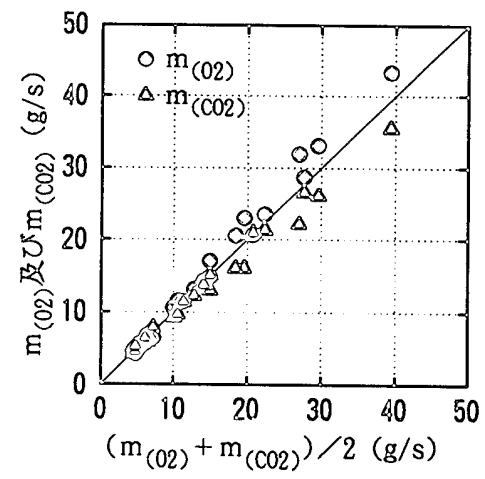

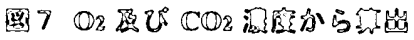

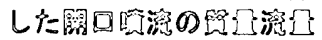

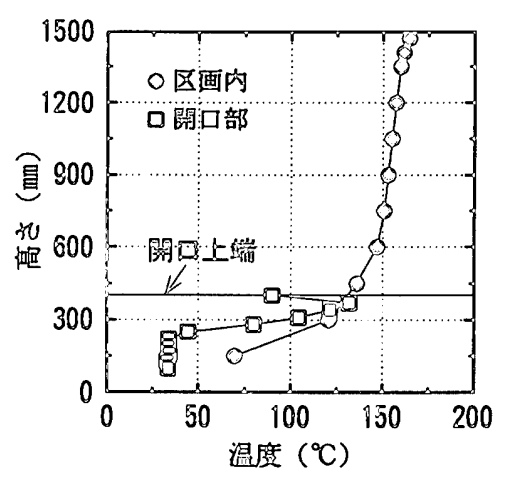

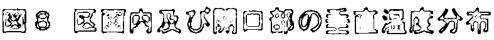

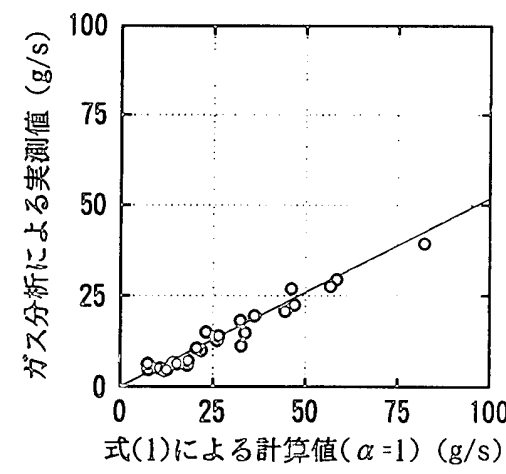

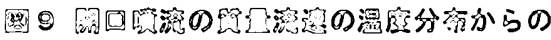

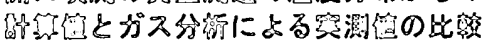




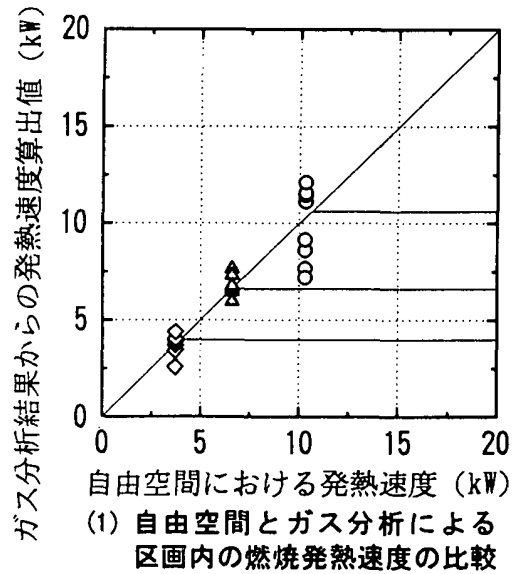

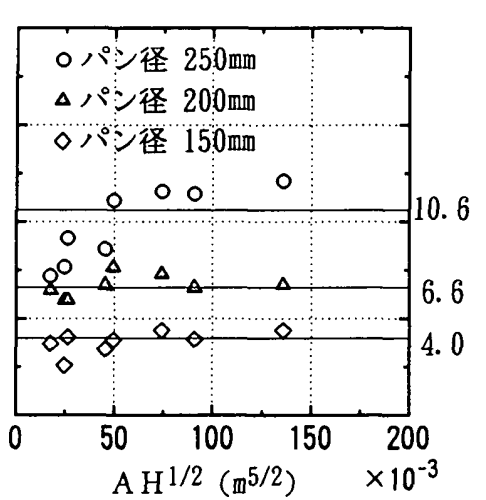

(2) 開口因子 $\left(\mathrm{AH}^{1 / 2}\right)$ と区田内 火源の発熱速度

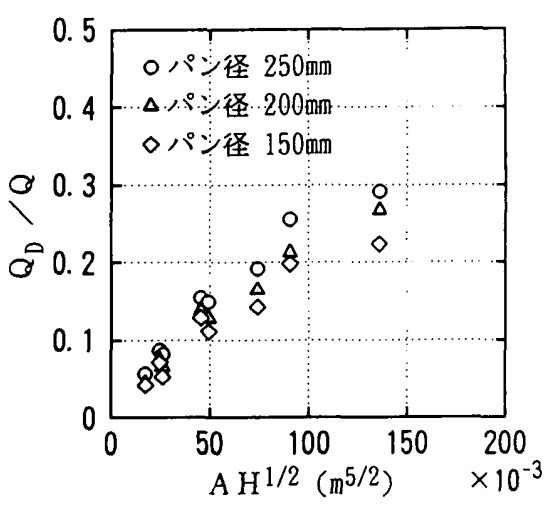

図11開口噴流により持ち出される熱量の 発熱速度に対する割合と開口条件
まず、本実験中の発熱速度の方が大きくなっているのは、区画内 高温ガスからの対流及び輻射熱伝達、周壁からの輻射熱伝達により メタノールが加熱されて、自由空間中での燃焼に比較し、蒸発速度 が大きくなっていることが原因と考えられる。

また、本実験中の発熱速度の方が小さくなっているのは、開口が 小さいときで、この場合換気量が少ないために区画内部での発熱が 抑えられ、その結果メタノールの蒸発速度が低下していることが原 因と考えられる。このことは図 10 (2)で、 $\mathrm{AH}^{1 / 2}$ によって発熱速 度が変化していることからも窥える。

\section{5 開口噴流により運ばれる熱量}

熱伝達性状を調べる際には開口噴流により持ち出される熟量QD を把握することが必要となる。そこで、開口噴流により持ち出さ れる熟量の発熱速度に対する割合を、開口形状を表すパラメータ $\mathrm{AH}^{1 / 2}$ に対してプロットした結果を図 11 に示す。ここで、開口 噴流により持ち出される熱量を算出する際に必要な開口噴流の温度 には、中性带高さから開口上端高さまでの平均值を用いた。この場 合も式 (35) 中の Nの值は0.1を用いたが、0.3としても開口噴流の温 度の変化は $2 \sim 3 \mathrm{~K}$ で、熱量の值への影響は微小であった。

図 11 では、開口噴流により持ち出される熱量の割合が、開口因 子 $\mathrm{AH}^{1 / 2}$ が大きくなるに従って增加する傾向が見られる。

\section{6. まとめと今後の眯題}

区画火災における開口噴流プルームと対流熱伝達の性状を調べる 研究の第一段階として、模型区画内の開口噴流の流量をガス分析に 基づいて測定した。その結果次のような知見が得られた。

(1) 開口噴流の流量を、 $\mathrm{O}_{2}$ 濃度及び $\mathrm{CO}_{2}$ 潾度からそれぞれ算出し た結果はほぼ一致した。一部に一致の十分でない測定值も見られ るが、模型区画の開口を通る流量が微小であることを考慮すれば、 本論文の測定手法は有力であると考えられる。

(2) 開口噴流の流量について、ガス浱度による算出值と温度による 算定式 (1)による予測值とを比較した結果、開口の流量係数 $\alpha$ を 0.52 とすると、両者が比較的良く一致した。この開口の流量係数 に值は既往の測定值に比較して若干小さめであるが、それ程大き くはずれるものではない。

(3) ガス分析の結果から算出した発熱速度と、自由空間における重 量堿少速度から算出した発熱速度の実測値と比較した結果、前者 は平均的には後者とはほぼ一致したが、個別に見ると前者の值は 後者とかなり差が見られるものもあった。これはメタノールの蒸 発速度が開口因子により変化するためと考えられる。

今後は、本研究における開口噴流の実験結果を用い、開口噴流 プルーム及び対流熱伝達の性状に関する分析を行う予定である。

\section{[期辞]}

実睮に際しては神田浩徳君、細沢貴史君（当時東京理科大学理工 学部卒論生)のご協力をいただいた。ここに記して感謝いたします。

注1）開口端では、開口噴流の縮流と周边空気の踒引のため、噴出気流の温度 が正確に测定できない。そこで、熱電対の開口端からの距離を变化させな がら、指示温度を区画内の同し高さにおける温度と比較した結果、開口端 から30mmの位贯で、区画内とほほ同じ温度を示したので、この位置の温度 で啫出気流の温度を代表できると考えた。

注2）表3から開口噴流の流量自。は4.5〜39.4g/sとなっている。また、メ夕

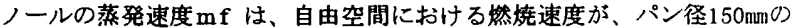
時 $0.18 \mathrm{~g} / \mathrm{s} 、 200 \mathrm{~mm}$ の時 $0.33 \mathrm{~g} / \mathrm{s} 、 250 \mathrm{~mm}$ の時 $0.50 \mathrm{~g} / \mathrm{s}$ 程度であり、图 $10(2)$ か ら区画内における燃焼速度の最大值もこれと大差はないと推定される。 一方、再上は図6の例に示すようにm。より常に大であるので、mf はm。 に比べて十分に小さいことがわかる。

[纪易]

\begin{tabular}{|c|c|}
\hline A & : 開口面積 $\left(\mathrm{m}^{2}\right)$ \\
\hline B & : 開口幅 (m) \\
\hline$C_{p}$ & ：定圧比熱（kJ/kg K） \\
\hline $\mathbf{g}$ & : 重力加速度 $\left(=9.8 \mathrm{~m} / \mathrm{s}^{2}\right)$ \\
\hline $\mathrm{H}$ & : 開口高さ (m) \\
\hline$M$ & ：モル分子量 $(\mathrm{kg} / \mathrm{mol})$ \\
\hline m & : 质量流速（kg/s） \\
\hline Q & $\begin{array}{l}\text { : 発熱速度または } \\
\text { エンタルピー量 }(\mathrm{kW})\end{array}$ \\
\hline $\mathrm{T}$ & : 温度（K） ～～ \\
\hline $\mathrm{x}$ & : 体㮴分率 $\left(\mathrm{m}^{3} / \mathrm{m}^{3}\right)$ \\
\hline & $\begin{array}{l}\text { : 兵量分率 }(\mathrm{kg} / \mathrm{kg}) \\
\text { 中中性带高さ (m) }\end{array}$ \\
\hline
\end{tabular}

$$
\begin{aligned}
& \alpha ： \text { 流量保数 } \\
& \rho: \text { 空気密度 }\left(\mathrm{kg} / \mathrm{m}^{3}\right) \\
& \text { 添字 } \\
& \text { A : カスス分析器による指示值 } \\
& \text { a : 周边空気 } \\
& \text { D : 開口喷流 } \\
& \text { E ：大フードに捕集されたカス } \\
& \text { f : 火源からの蒸発 } \\
& \text { i : 開口加ら流入空気 } \\
& \mathrm{L} \text { : ガスの種類 }(\mathrm{O} 2, \mathrm{CO} 2, \mathrm{~N} 2, \mathrm{H} 2 \mathrm{O}) \\
& \mathrm{P} \text { : 開口噴流プルーム } \\
& \text { ニ小フードから流出するカス } \\
& \text { s : 火災区画 }
\end{aligned}
$$

\section{[类考文献]}

1) 横井鎮男 : Study on the Prevention of Fire-Spread Caused by Hot Upward Current、建築研究報告 No.34、1960

2）田中哱義：小規模建築物の火災のモデル化に関する研究(3)一火災時の流 れに関するモデ化一、日本火炎学会論文集 Vol.30、No.1、pp.7.18、1980 3）山田茂、田中㼁、吉野博：小規模区画における火災初期の対流熱伝澾、 日本建筑学会計画系馀文集 第 491 号、p.1-8、1997.01

4）石野修、田中㫴義：アトリウム空間の自然排煙効果に関する研究、日本 建策学会栱造系諭文報告集 第 451 号、pp.137-144、1993.09

5) B.M.Cetegen. E.E.Zukoski, T.Kubota : Entrainment in the Near and Far Field of Fire Plumes, Combustion Science and Technology, Vol.39, pp.305-33, 1984

6）山田茂、田中睟荺、吉野博：熱伝達率と発熱速度及び区画規模との関係 一小規槙区画に扮ける火炎初期の対流熱层達その2、日本貄筑学会計画系 諭文集 第 495 号、p.1-8、1997.05

7) Cooper, M.Harkleroad, J.Quintiere, W.Rinkinen : AnExperimental Study of Upper Hot Layer Stratification in Full-Scale Multiroom Fire Scenarios, Journal of Heat Transfer, Vol.104,pp.741-749, 1982.11

8) J.Prahl and H.W.Emmons : Fire Induced Flow through an Opening, Combustion and Flames, Vol.25, pp.369-385, 1975

9) I.Nakaya, T.Tanaka, M Yoshida : Doorway Flow Induced by a Propane Fire, Fire Safety Journal, Vol.10, pp.185-195, 1986

10) 今井功：流体力学（前編）、蓄華房、p.51

（1996年12月10日原稿受理，1997年 6 月13日採用決定） 